\title{
Epidural versus intravenous clonidine for postoperative patient controlled analgesia
}

\author{
Soaad A. Lotfy *, Soaad A. Mansour *,Tarek M. El Said * \\ Amal M. Abd El Fattah **and Amal Abd El Aleem morsy** \\ Departments of Anaesthesiology *and clinical pathology** \\ Faculty of medicine for girls - Al Azhar university
}

\begin{abstract}
unlike most other sedative drugs, $\propto 2$ adrenoceptor agonists e.g (clonidine) are capable of producing both sedation and analgesia with little if any, respiratory change. The aim of this study was to evaluate the analgesic efficacy, the respiratory and the endocrine effects of epidural versus intravenous clonidine for postoperative pain. Forty adult patients ASA I and II of both sexes were scheduled for elective lower abdominal or lower extremity surgical procedures. For postoperative pain relief, the patients were randomly divided into two groups, twenty patient of each. In (Group I) patients received intravenous clonidine through patient-controlled analgesia pump (IPCA). In (Group II) patients received epidural clonidine through patient-controlled analgesia pump (EPCA).

A standard anaesthetic technique was employed to all patients and anaesthesia was maintained with gas oxygen halothane and muscle relaxant. Serial arterial and venous blood samples were taken to measure blood gases and endorphin level. After surgery patients with visual analogue scale ( VAS ) $>4$ were given clonidine initial dose $4 \mu \mathrm{g} / \mathrm{kg}$ intravenous or epidural infusion over a period of 30 minutes then they were allowed to self administer clonidine using PCA pump which delivered a bolus dose of $0.5 \mu \mathrm{g} / \mathrm{kg}$ with a 15 minute lockout interval to the corresponding route.

Self-administered doses were $(124.2 \pm 34.637 \mu \mathrm{g})$ in intravenous group and $(100.6 \pm 31.406 \mu \mathrm{g})$ in epidural group. The total clonidine dose was $(424 . \pm 38.138 \mu \mathrm{g})$ in intravenous group versus $(399.8 \pm 47.371 \mu \mathrm{g})$ in epidural group. Pain scores were lower after than before clonidine administration in both groups . No significant difference in pain scores were found between the two groups. There was also no significant changes in respiratory rate, arterial $\mathrm{PH}, \mathrm{PaCo} 2$ or $\mathrm{Pa}$ o 2 in each studied group and no significant difference between the two groups. Forced vital capacity ( FVC ) and Forced expiratory volume in one second ( FEV1) were significantly reduced before clonidine injection in both groups. The beta endorphin level was increased after one hour of clonidine administration and there was no significant difference between the two groups. In conclusion Clonidine proves to be adequate alternative to opiates without their side effects and the dose of clonidine is lower by the epidural route.
\end{abstract}

\section{Introduction}

There is great evidence that unrelieved postoperative pain may result in harmful physiological and psychological effects and good pain relief may help to decrease postop erative morbidity (Ready,2000). Anaesthesia and surgery are associated with dramatic decrease in functional 
residual capacity (FRC) resulting in basal atelectasis and development of pulmonary shunts (Jones et al., 1990) . Postoperative pain hinders patients from coughing effectively and co-operating in chest physiotherapy (Stoelting 1999), that may decrease the tidal volume (TV), vital capacity (VC) and peak expiratory flow rate (PEFR). Unlike most other sedative drugs, $\propto 2$ adreno ceptor agonists are capable of prod ucing both sedation and analgesia with little if any, respiratory change (Bernard et al., 1995) that makes them potentially useful in the postoperative non ambulatory settings and in intensive care situations (Hall et al.,2001) . Clonidine, a centrally acting $\propto 2$ receptor agonist has a beneficial effect before, during and after anaesthesia such as, sedation, analgesia, increased cardiovascular stability and improved outcome (Kamibayashi and Maze, 2000) and (Fehretal., 2001).

There is currently considerable interest in attempting to combine the potent analgesic effects of drugs delivered into the epidural space with the advantage of patient participation associated with the patient-controlledanalgesia (PCA) concept. PCA system was designed whereby patients could administer their own pain relief drug and so titrate the dose to their own endpoint of adequate analgesia (Kluges 1990).

The aim of this study was to evaluate the analgesic efficacy, the respiratory and the endocrine effects of epidural versus intravenous clonidine for postoperative pain relief.

\section{Patients and Methods}

Forty adult patients ASA I and II of both sexes aged between 18-55 years admitted to Al Zahraa university hospital and were scheduled for elective lower abdominal or lower extremity surgical procedures. For postoperative pain relief, the patients were randomly divided into two groups, twenty patient of each:

Group I: Patients received intravenous clonidine through (IPCA)pump.

Group II : Patients received epidural clonidine through (EPCA )pump.

Patients who showed evidence of cardiovascular, respiratory, renal or hepatic dysfunction and patients with abnormal coagulation profile were excluded. The study protocol was explained to the patients taking their consent. Patients were instructed how to use the PCA device, and to describe the threshold of postoperative pain on the visual analogue scale (VAS).

\section{Equipment :}

Patient-controlled analgesia device : a self administered analgesic pump (Abbot life provider).

All patients in the two groups received $5 \mathrm{mg}$ midazolam orally at the night of operation.

\section{Prior to induction of anaesthesia :}

In group I " 18 " gauge cannula was placed for clonidine injection and PCA device.

In group II : a lumbar epidural technique midline approach was employed under complete aseptic conditions, where a touhy needle was inserted between lumbar level L3 - L4 or L4 - L5 interspace, position of the needle was identified by loss of resistance and an epidural catheter was introduced.

Induction was achieved by thiopentone 4-6 mg/kg and succinylcholine $1 \mathrm{mg} / \mathrm{kg}$ and anaesthesia was maintained with $60 \%$ nitrous oxide in oxygen, halothane $0.5-1.5 \%$. Muscle paralysis was achieved by atracurium $0.5 \mathrm{mg} / \mathrm{kg}$ with controlled ventilation.

A 20 gauge cannula was inserted in the radial artery of the left hand of 
the patients after positive Allen's test, and flushed with heparinized saline solution to allow serial measurements of arterial blood gases. Intraoperative monitoring included : ECG, non inva sive arterial blood pressure, pulse oxi metry and capnography, and conti nued 24 hour after clonidine adminis tration . No additional analgesics or tranquilizers were administered imme diately after operation.

At the first complaint of pain, patients with VA $\mathrm{S}>4$ were given clonidine (catapress) (Boehringer Inge lheim. UK.) as $150 \mu \mathrm{g} / \mathrm{ml}$ in ampoules of $1 \mathrm{ml}$.

All patients received an initial loading dose of $4 \mu \mathrm{g} / \mathrm{kg}$ clonidine intravenous or epidural infusion over a period of 30 minute, then the patients were allowed to self administer cloni dine using PCA pump which delive red a blouse dose of $0.5 \mu \mathrm{g} / \mathrm{kg}$ with a 15 minute lockout interval to the corresponding route. Data were recor ded at the following times :

Before clonidine administration, at 15 and 30 minutes during infusion of loading dose $4 \mu \mathrm{g} / \mathrm{kg}$., and at $2,4,6,8$, 12,24 hours after the loading dose and during the use of PCA device.

Respiratory rate was recorded. Arterial blood gases were measured by blood gas analyzer [CHIRON Diagnostic 248 Rapid-lab] before clonidine administration, then $30 \mathrm{~min}$, 4 hours and 24 hours after clonidine administration..

Pulmonary function tests were done by Respirometer (Jaeger flowmate). Forced vital capacity (FVC) and forced expiratory volume in one second (FEV1) were measured preoperative, postoperative during pain, $12 \mathrm{hr}$ and $24 \mathrm{hr}$ after clonidine administration.

Any side effects were observed and treated as follow : hypotension was treated by i.v. fluids or $3 \mathrm{mg}$ ephedrine i.v. Bradycardia was treated by $0.5-1$ $\mathrm{mg}$ atropine i.v.Inadequate analgesia : if the patient required analgesia in addition to self-administered doses of clonidine.

Sampling : Blood samples were taken to measure plasma level of betaendorphin. Samples time was recorded before administration of clonidine and 1 hour after the first dose of clonidine. Blood was collected in tubes containing EDTA and Trasylol (5000 Kiu trasylol in $10 \mathrm{ml}$ vacutainer tube). The samples were cooled in an ice-bath immediately, and centrifuged at $4^{\circ} \mathrm{c}$. The plasma should be frozen within one hour and stored at $-20^{\circ} \mathrm{c}$ until assay. Beta endo rphin in sample was extracted using Sep-Pak C 18 cartridges. The extracts were analysed by competitive radio immunoassay using antibody against synthetic human B-endorphin.

B-endorphin in standards and samples compete with 125 I labelled B-endorphin in binding to the antib odies. 125 I B-endorphin binds to the antibodies in a reverse proportion to concentration of B-endorphin in stand ards and samples. Antibody bound 125 I B-endorphin was separated from the fraction using the double antibody polyethylen glycol precipitation techn ique, the radioactivity of the precipitates was measured. (Kits supplied from Gama trade company)

\section{Statistical analysis :}

All variables were expressed as mean \pm SD. Comparison of patients within the same group were evaluated by using non-parametric Wilcoxon Signed-rank test. Paired simple t-test was used for comparison between groups. P-value of less than 0.05 denote a significant difference.

\section{Results:}

Demographic data were comp arable for age, weight, height and sex as shown in table (1). 
There were no significant differences between the two groups.

The initial dose of clonidine was identical in both groups (301.2 \pm 37 . $480 \mu \mathrm{g}$ ) in the intravenous group and $(299.2 \pm 36.374 \mu \mathrm{g})$ in the epidural group. But, the clonidine dose given via the PCA device to achieve a comparable pain relief level was lower in epidural group.

Self-administered dose were $(124.2 \pm 34.637 \mu \mathrm{g})$ in intravenous group and $(100.6 \pm 31.406 \mu \mathrm{g})$ in epidural group.

The total clonidine dose was (424. $\pm 38.138 \mu \mathrm{g})$ in intravenous group versus $(399.8 \pm 47.371 \mu \mathrm{g})$ in epidural group (table 2)

VAS before clonidine injection showed no significant difference in both groups (table 3).

Pain scores were lower after than before clonidine administration in both groups with no significant difference between the two groups ( Figure 1).

Presence of pain in the posto perative period have been expected to induce an alteration in pulmonary functions. Respiratory rate was unchanged throughout the study for both groups. Analgesia did not result in significant changes in respiratory rate (table 4). There was also no significant change in arterial $\mathrm{PH}, \mathrm{Pa} \mathrm{Co} 2$ or $\mathrm{Pa} 02$ in each studied group throughout the observation time and no significance between the two groups (table 5), but FVC and FEV, were significantly reduced before injection of clonidine in both groups compared to baseline (preoperative) spirometric parameters (Figures $3 \& 4$ ).Eight hours postinjection, there were significant impro vement in pulmonary function tests but this improvement was still low than the baseline values till the end of the study (table 6)(Figures $3 \& 4$ ). There were no statistical significant differences in pulmonary function tests between both groups (table 6 ) (Figures 3\&4).

As regards, beta endorphin, both groups showed increase in plasma concentration of beta-endorphin after one hour of clonidine administration. There was no significant difference between both groups table $(7)$ Figures(4).

Table 1 :Demographic data. Values are represented as mean \pm SD. There are no significant differences between the two groups.

\begin{tabular}{|l|l|l|}
\hline & $\begin{array}{l}\text { Group 1 (IPCA) } \\
\mathrm{N}=20\end{array}$ & $\begin{array}{l}\text { Group1 (EPCA) } \\
\mathrm{N}=20\end{array}$ \\
\hline Age $(\mathrm{yr})$ & $32.2 \pm 10.30$ & $29.4 \pm 8.70$ \\
Weight $(\mathrm{kg})$ & $59.0 \pm 9.46$ & $65.8 \pm 10.06$ \\
Height $(\mathrm{cm})$ & $163.4 \pm 10.11$ & $165 \pm 9.50$ \\
Sex $(\mathrm{M} / \mathrm{F}$ & $9 / 11$ & $12 / 8$ \\
\hline
\end{tabular}

Table 2 :Doses of clonidine in both groups values are represented as mean \pm SD.

- $\mathrm{P}$ value $<0.05$ between groups.

\begin{tabular}{|c|c|c|c|c|}
\hline & \multicolumn{2}{|c|}{ Group I } & \multicolumn{2}{|c|}{ Group II } \\
\hline & Mean & \pm SD & Mean & \pm SD \\
\hline $\begin{array}{l}\text { Initial dose } \\
\text { Self-administered dose } \\
\text { Total dose }\end{array}$ & $\begin{array}{l}\mathbf{3 0 1 . 2} \\
124.2 \\
425.4\end{array}$ & $\begin{array}{l}\mathbf{+ 3 7 . 4 8 0} \\
\pm 34.637 \\
\pm 38.138\end{array}$ & $\begin{array}{l}\mathbf{2 9 9 . 2} \\
100.6 \\
399.8\end{array}$ & $\begin{array}{l}\mathbf{\mathbf { 3 6 } 6 . 3 7 4} \\
\mathbf{\pm 3 1 . 4 0 6} \\
\pm 57.371 *\end{array}$ \\
\hline
\end{tabular}


Table 3 : Visual analogue scale (VAS). Values are represented as mean \pm SD. There are no significant differences between groups.

\begin{tabular}{|l|l|l|l|l|}
\hline \multirow{2}{*}{ time } & \multicolumn{2}{l|}{ Group I (IPCAA) } & \multicolumn{2}{l|}{ Group II(EPCA) } \\
\cline { 2 - 5 } & Mean & SD & Mean & SD \\
\hline Before & 8.6 & $\mathbf{\pm 0 . 9 4}$ & 8.2 & $\mathbf{0 . 8 2}$ \\
$15 \mathrm{~min}$ & 3.3 & \pm 0.75 & 3.3 & \pm 0.97 \\
$30 \mathrm{~min}$ & 2.5 & \pm 0.60 & 2.2 & \pm 0.71 \\
$2 \mathrm{hr}$ & 2.6 & \pm 0.55 & 1.8 & \pm 0.48 \\
$4 \mathrm{hr}$ & 2.9 & \pm 0.68 & 1.9 & \pm 0.68 \\
$6 \mathrm{hr}$ & 2.25 & \pm 0.76 & 2.1 & \pm 0.76 \\
$8 \mathrm{hr}$ & 2.7 & \pm 0.44 & 2.4 & \pm 1.31 \\
$12 \mathrm{hr}$ & 2.1 & \pm 0.58 & 2.3 & \pm 0.81 \\
$24 \mathrm{hr}$ & 1.9 & \pm 0.64 & $\mathbf{2 . 2}$ & \pm 0.91 \\
& & & & \\
\hline
\end{tabular}

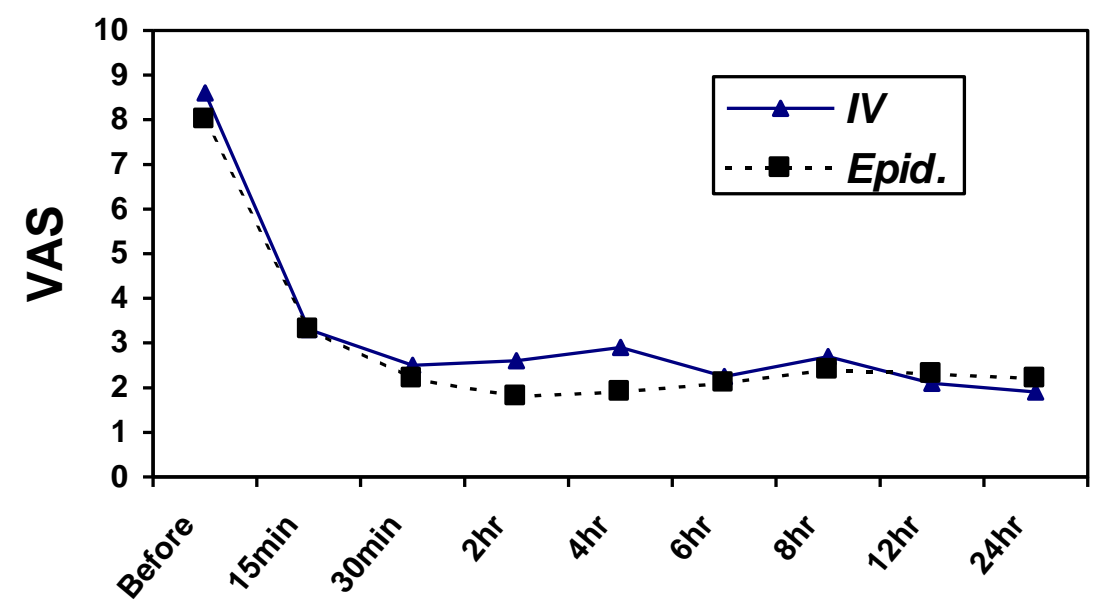

Time

Figure 1: Visual analogue scale (VAS). Values are represented as mean.

Table 4 : Respiratory rate changes. Values are represented as mean $\pm \mathrm{SD}$. There are no inter-group differences. P value $>0.05$.

\begin{tabular}{|c|c|c|c|c|}
\hline \multirow[t]{2}{*}{ time } & \multicolumn{2}{|c|}{ Group I (IPCAA) } & \multicolumn{2}{|c|}{ Group II(EPCA) } \\
\hline & Mean & SD & Mean & SD \\
\hline Before & 20.4 & \pm 2.10 & 20.8 & \pm 2.75 \\
\hline $15 \mathrm{~min}$ & 19.5 & \pm 2.51 & 20.4 & \pm 1.38 \\
\hline 30min & 19.0 & \pm 2.27 & 20.1 & \pm 2.37 \\
\hline $4 \mathrm{hr}$ & 21.0 & \pm 2.82 & 20.7 & \pm 2.84 \\
\hline $12 \mathrm{hr}$ & 18.7 & \pm 1.94 & 20.0 & \pm 2.22 \\
\hline $24 \mathrm{hr}$ & 19.2 & \pm 1.89 & 20.1 & \pm 1.71 \\
\hline
\end{tabular}


Epidural versus intravenous clonidine

Table 5 : Changes in FVC and FEV1, values are represented as mean $\pm \mathrm{SD}$. $* \mathrm{P}$ value $<0.05$ compared with baseline.

\begin{tabular}{|l|l|l|l|l|}
\hline & $\begin{array}{l}\text { Pre- } \\
\text { operative }\end{array}$ & $\begin{array}{l}\text { During } \\
\text { pain }\end{array}$ & After 8 hr & After 24hr \\
\hline FVC & $3.68 \pm 0.67$ & $0.64 \pm 0.23^{*}$ & $2.33 \pm 0.43^{*}$ & $2.81 \pm 0.44^{*}$ \\
Group I & $3.74 \pm 0.65$ & $0.76 \pm 0.24^{*}$ & $2.04 \pm 0.53^{*}$ & $2.57 \pm 0.62^{*}$ \\
Group II & & & & \\
FEV1 & & & & \\
Group I & $2.60 \pm 0.71$ & $0.46 \pm 0.35^{*}$ & $1.63 \pm 0.51^{*}$ & $1.94 \pm 0.53^{*}$ \\
Group II & $3.05 \pm 0.54$ & $0.54 \pm 0.28^{*}$ & $1.61 \pm 0.45^{*}$ & $2.15 \pm 0.58^{*}$ \\
\hline
\end{tabular}

\section{Intravenous Group}
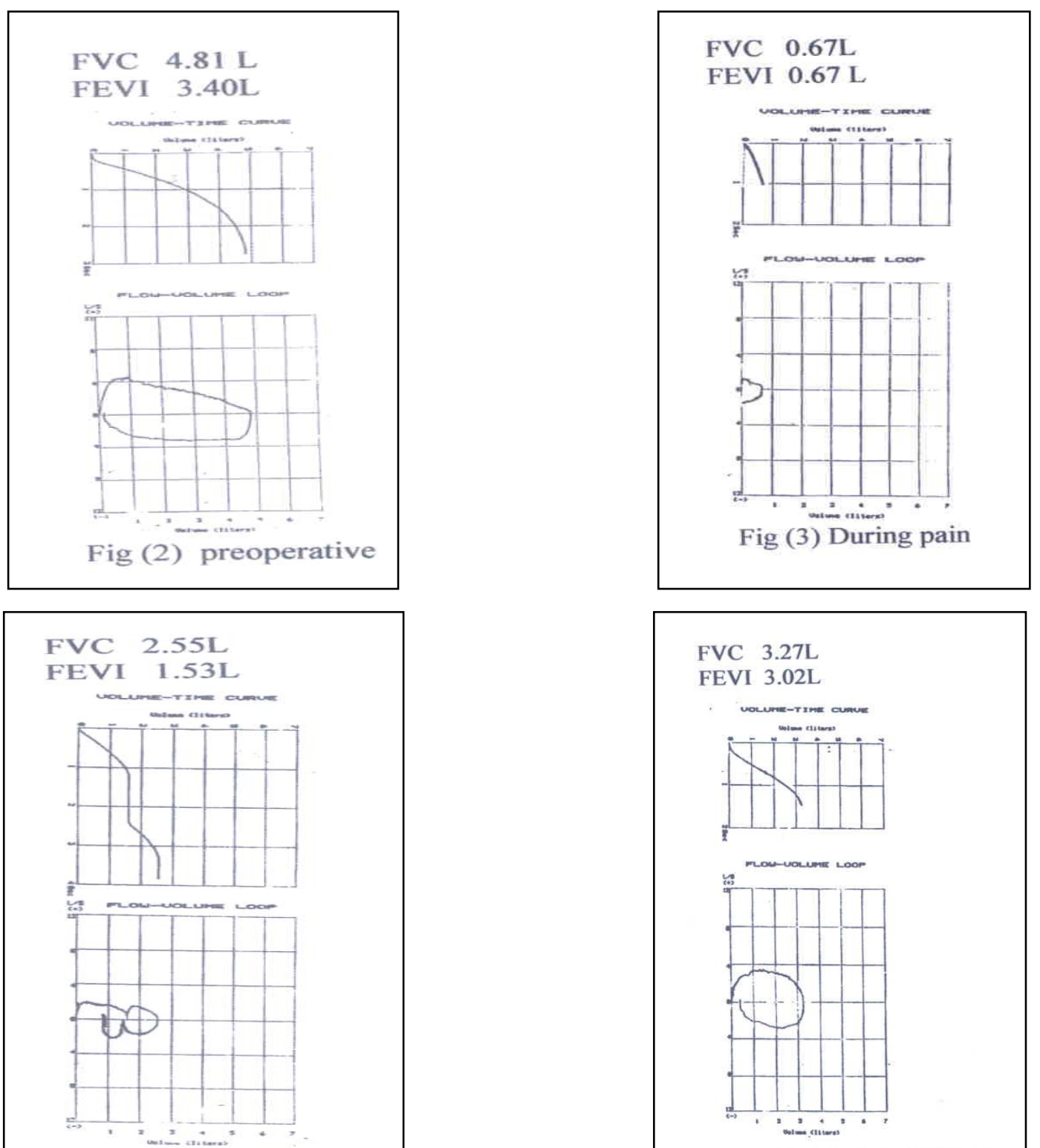

Fig (4) After 8 hours

FVC $3.27 \mathrm{~L}$

FEVI $3.02 \mathrm{~L}$
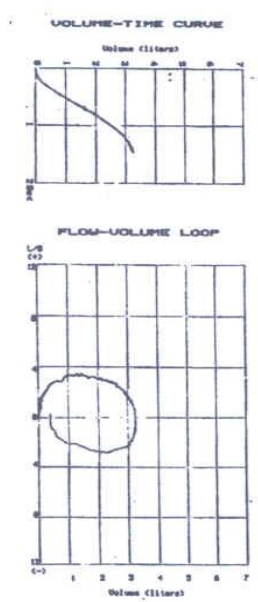

Fig (5) After 24 hours 
Soaad A. Lotfy et al

\section{Epidural group}

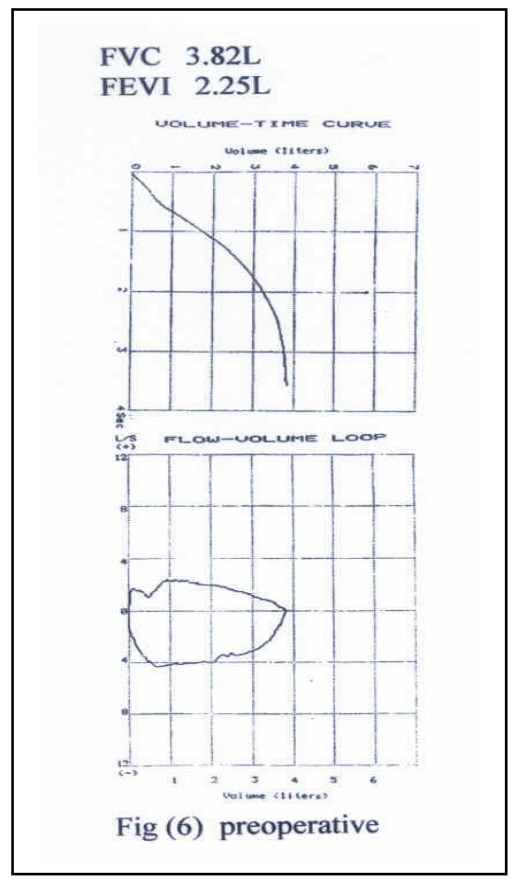

FVC $0.56 \mathrm{~L}$

FEVI $0.51 \mathrm{~L}$

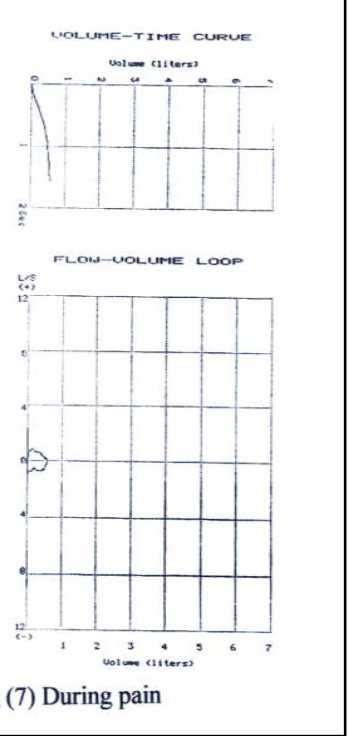

FVC $1.90 \mathrm{~L}$

FEVI $1.40 \mathrm{~L}$
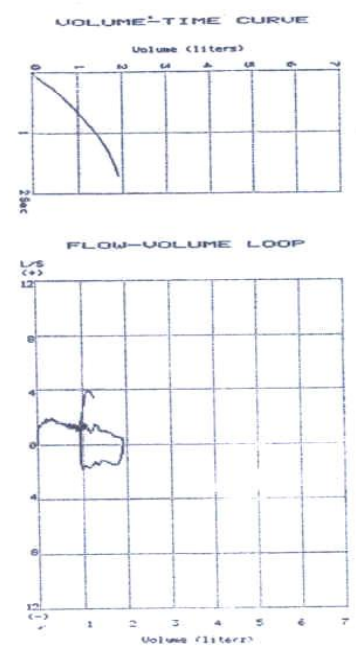

Fig (8) After 8 hours

FVC $2.41 \mathrm{~L}$

FEVI $1.74 \mathrm{~L}$

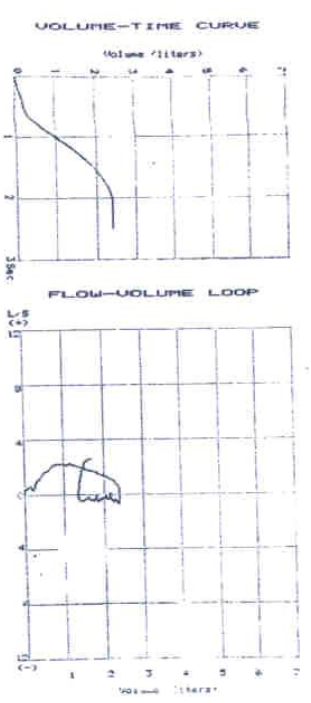

Fig (9) After 24 hours 
Epidural versus intravenous clonidine

Table 6 : Arterial blood gas analysis. Values are represented as mean \pm SD. There are no inter-group differences.P value $>0.05$.

\begin{tabular}{|l|l|l|l|l|}
\hline & Before & 30min & 4hr & 24hr \\
\hline PH & & & & \\
Group I & $7.41 \pm 0.02$ & $7.40 \pm 0.01$ & $7.40 \pm 0.02$ & $7.39 \pm 0.03$ \\
Group II & $7.39 \pm 0.02$ & $7.40 \pm 0.01$ & $7.39 \pm 0.02$ & $7.41 \pm 0.01$ \\
PaCO $_{2}(\mathrm{mmHg})$ & & & & \\
Group I & $38 \pm 3.27$ & $39 \pm 2.23$ & $38 \pm 3.17$ & $38 \pm 2.08$ \\
Group II & $39 \pm 3.22$ & $39 \pm 2.20$ & $40 \pm 2.30$ & $39 \pm 3.14$ \\
PaO $_{2}(\mathrm{mmHg})$ & & & & \\
Group I & $88 \pm 10.47$ & $89 \pm 8.69$ & $89 \pm 7.09$ & $90 \pm 8.31$ \\
Group II & $92 \pm 8.38$ & $90 \pm 8.72$ & $90 \pm 9.21$ & $89 \pm 7.81$ \\
\hline
\end{tabular}

Table 7 : Changes of beta-endorphin. Value are represented as mean \pm SD.P value > 0.05 compared to (pre-injection)

\begin{tabular}{|l|l|l|l|l|}
\hline \multirow{2}{*}{ Time } & \multicolumn{2}{|l|}{ Group I (IPCAA) } & \multicolumn{2}{l|}{ Group II(EPCA) } \\
\cline { 2 - 5 } & Mean & SD & Mean & SD \\
\hline Before injection & 22.8 & \pm 3.001 & 21.6 & \pm 4.333 \\
After one hour & 24.9 & \pm 3.636 & 23.2 & \pm 4.785 \\
\hline
\end{tabular}

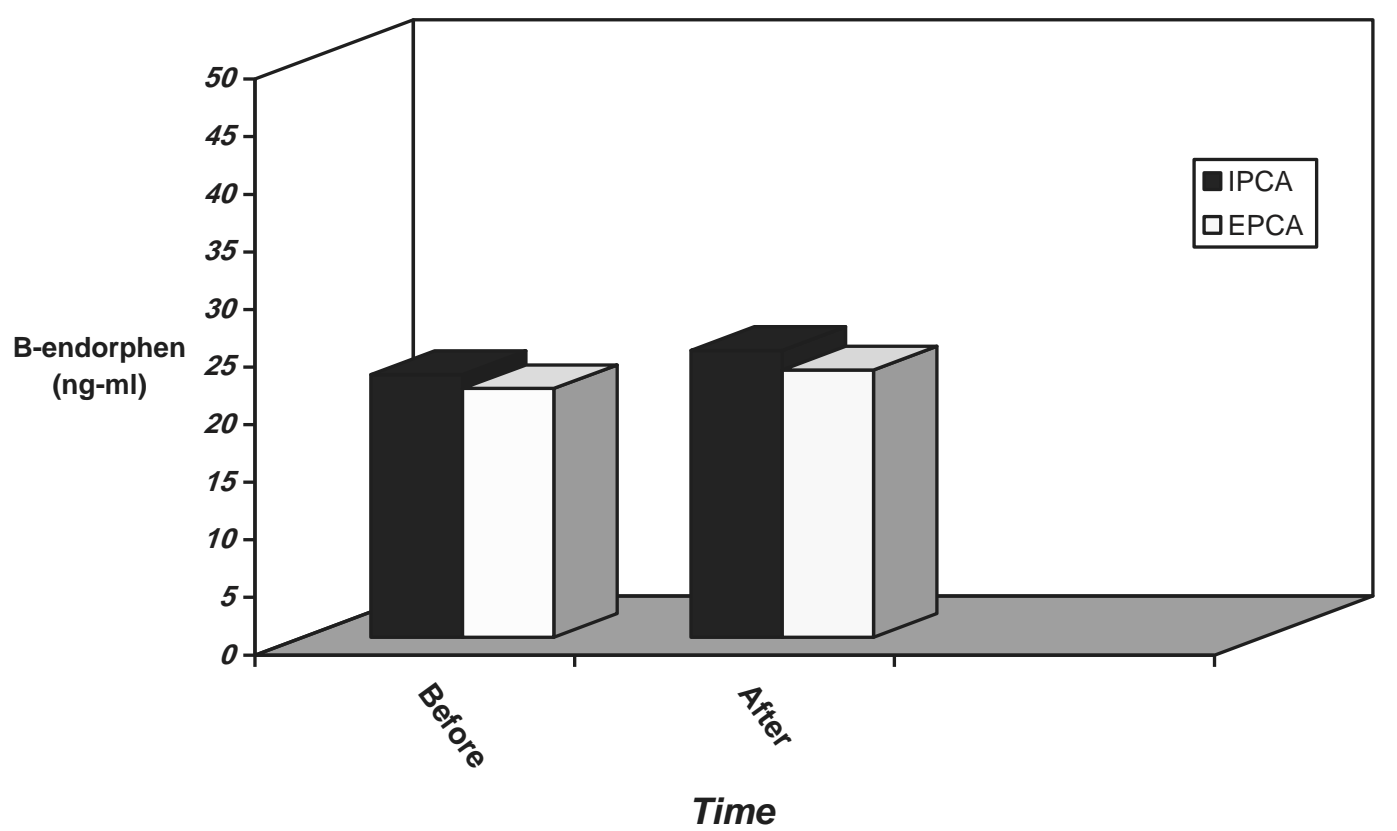

Figure10 : Changes in plasma level of beta-endorphin. Values are represented as mean 


\section{Discussion}

Postoperative pain is a great problem that may cause indirectly, adverse effects on various organ syst ems. The efficacy of clonidine admini stration continue to be shown in acute postoperative pain management. It has been proved that epidural clonidine is an adequate alternative to opiates in prolonging the duration of analgesia provided by local anaesthetics (cook et al., 1995).

Several attempts have been made to compare epidural and systemic administration of clonidine (De Kock et al., 1993).

This study investigated the analgesic and respiratory effects of clonidine when administered either intravenously or epidurally through patient controlled analgesia device. Clonidine was used as a sole analgesic after surgical procedures involving the abdomen or the lower extremities to assess whether these two administration routes were clinically equivalent and to document differences in doses required to achieve the same level of analgesia. In the present study intravenous or epidural doses ranging from $250-350 \mu \mathrm{g}$ of clonidine were given as an initial dose or $350-500 \mu \mathrm{g}$ as a total dose for pain relief which were relatively low doses if compared with other studies, as shown by Eisenach et al., 1989) who used clonidine doses ranging from 100$900 \mu \mathrm{g}(100 \mu \mathrm{g}$ increments) in patients following total knee, arthroplasty or abdominal surgery. Also de kock et al., (1993) used total dose of clonidine from $800-1000 \mu \mathrm{g}$ in his study. It has been proved that a fixed continuous infusion usually overestimates patient require ments when compared to patientcontrolled analgesia administration (Bouddreault et al.,1991). Bonnet et al.,(1989) observed that epidural clonidine $2 \mu \mathrm{g} / \mathrm{kg}$ produced brief but significant pain relief after peripheral orthopedic surgery.

In this study, both intravenous and epidural clonidine administration, using patient-controlled analgesia device, provided complete postoperative analgesia. There was no significant difference in pain scores between the two groups. Reduction of clonidine requirements by the use of epidural route provides, indirect evidence that analgesia appears to be better after epidural than intravenous administration of clonidine, and clearly indicates that spinal cord is the main site for the analgesic addition of clonidine . this finding is consistent with the Iwork of (Eisenach et al., 1993) and (Bernard et al.,1995) who used clonidine epidurally and intravenously as a sole analgesic agent for postoperative pain relief. In contrast, the findings of Carroll et al., (1993) who reported that $150 \mu \mathrm{g}$ bolus dose of intravenous clonidine gives better results than the same dose admi nistered epidurally

Restriction in respiratory funct ions following surgical trauma was reported by different studies (Nishino et al., 1988) and it is common belief that good pain relief reduces the incidence of postoperative pulmonary complications.

In this study, respiratory rate and blood gases were unchanged through the study in both groups. No episodes of arterial oxygen saturation equal to or less than $95 \%$ were noted. These data were consistent with the results of (Berand et al., 1994) .

On the other side experimental studies showed that systemic clonidine had produced hypoxaemia in sheep (Eisenach and Dewan 1989) and epid ural clonidine produced mild increase in arterial pco2 (Eisenach et al., 1993). 
Restriction in respiratory function follo -wing surgical trauma was another similar study showing that intravenous but not intrathecal administration of alpha-2 adrenergic agonist results in substantial respiratory depression (Sabbe et al.,1994) .

In the present study, the onset of pain was accompanied by a severe restriction of pulmonary function test. The FVC and FEV1, were considerably and significantly reduced compared to preoperative levels in both groups. Pain relief with clonidine administration, resulted in a significant improvement in this reduction. However the values did not reach the preoperative level after 24 hr post injection.

It is well known that surgical trauma increases release of betaendorphin level in plasma (Kehlet, 1987) levy,1986 reported that plasma level of beta-endorphin increases three folds after surgical incision and remains elevated well in the postoperative period.

In this study, plasma levels of beta-endorphin were increased in both groups after clonidine injection but levels were within the estimated range. The normal range of this peptide in plasma between 16-48 $\mathrm{pg} / \mathrm{ml}$. Sxyfelbein et al., 1985 found that endorphin concentration was inversely proportional to acute pain, i.e. the greater the plasma concentration of Bendorphin the lower the reported pain. Plasma concentration of B-endorphin may be considered as a good indicator of endogenous pain modulation.

\section{Conclusion}

Clonidine proves to be adequate alternative to opiates without their side effects, like respiratory depression, itching, nausea and vomiting. It may be given by epidural or intravenous route for postoperative analgesia. The dose of clonidine is lower by the epidural route, indicating that it has specific action on sympathetic neurons of the spinal cord.

\section{References}

1. Bernard JM, Lagard D, Souron R., (1994) : Balanced postoperative analgesia : Effect of intravenous cloni dine on blood gases and pharmaco kinetics of intravenous fentanyl. Anesth Analg. 79:1126-32.

2. Bernard JM, Ottmar $K$ and Bonnet F 1995 : comparison of intravenous and epidural clonidine for postoperative patient controlled analgesia. Anaesth analg 81:706-12.

3. Bonnet F., Boico O, \& Rostaing S. (1989) : Postoperative analgesia with extradural clonidine, Br. J. Anaesth, 63:465-469.

4. Carroll D., Jadad A., and King T., 91993) : Single dose, randomized, double-blind, comparison of extradural and iv clonidine in chromic pain. Br. J. Anaesth. 71:665-9.

5. Cook B., Grubb DJ., Aldridge LA., and Dolle E., (1995) : Comparison of the effects of adrenaline, clonidine and Ketamine on the duration of caudal analgesia produced by bupivacaine in children- Br. J. An aesth., 75:698-701.

6. Dekack M., Crochet B., and Morimont C.,(1993) : Intravenous and epidural clonidine for intra-and postop erative analgesia. Anesthesiology, 79:525-31.

7. Eisenach JC., Det weiler D., and Hood D., 91993) : Haemodynamic and analgesic actions of epidurally admini stered clonidine. Anaesthesiology, 78 : 277-287.

8. Fehr SB, Salunardo Mp, Seifert B, Rentsch KM, Rohling RG, pasch T and Spahn DR (2001): Clonidine decreases proposal requirements during anaesthesia : effect on bispectral index British J of Anaesth., 86 (5) : 627-32.

9. Hall JE, Uhrich TD and Ebert TJ (2001) : Sedative, analgesic and cognitive effects of clonidine infusions 
in humans. British $\mathbf{J}$ of Anaesth., 86 (1) : 5-11.

10. Jones J., Sapsford D., and Wheatlely R. (1990) : Postoperative hypoxaemia : mechanisms and time course. Anaesthesia, $45:$ 566-73.

11. Kamibayashi TO and Maze M (2000) : Clinical uses of alpha 2 adrenergic agonists. Anesthesiology 93 : 1345-9.

12. Kehlet H. (1987) : Effects of postoperative pain on surgical outcome. In anaesthesiology and pain mana gement. Eds. Stanley $\mathrm{T} H$ and Ashburn M A Kluwer Academic publishers, New York, 171-175.

13. Kluger M. \& Owen H (1990) : Patients expectations of patient controlled analgesia. Anaesthesia 45 : 1072-4.
14. Nishino T., Hiraga K., Fujisa C. Mizu G., and Honda ( 1988) : Greeting patterns during post-operative analgesia in patients after lower abdominal operations. anaesthesiology, 69: 967-972.

15. Ready B (2000) : Acute preoperative pain In : Miller RD (ed) In Anaesthesia 5th ed. Churchill Living stone, New York pp 2323-2350.

16. Sabbe MB., Penning JP and Ozaki GT., (1994) : Spinal and systemic action of the alpha -2 receptor agonist in dogs. Anaesthesiology, $80: 1057$ 72.

17. Szy Felbein S., Osgood P., and Carr D. (1985) : The assessment of pain and plasma beta-endorphin immunoactivity in burned children, pain 22, 173-82. 


\title{
المقارنة بين حقن الكلونيدين خارج الأم الجافية وحقتة فى الوريد لتسكين

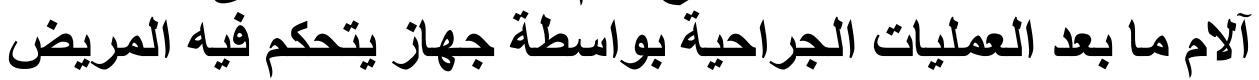

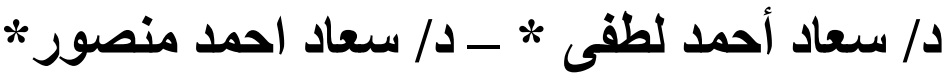 \\ د/ طارق محمد السعيد** ـ د/ أمل محمد عبد الفتاح** ـ ـــ/ أمل عبد العليم

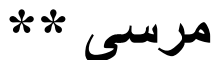 \\ أقسام التخدير والباثولوجيا الإكلينيكية بطب بنات الأزهر
}

إن العقاقير التى تميل الى مستقبلا ت الأدرينـالين (ألفـا 2) مثنل الكلونيدين تختلف عن معظم العقاقير المهيئة فى إنها تسكن الألم بدون تأثيثر على عملية التنفس

و الغرض من هذا البحث هو المقارنة بين تأثتير حقن الكلونيدين خارج الام الجافيهـ

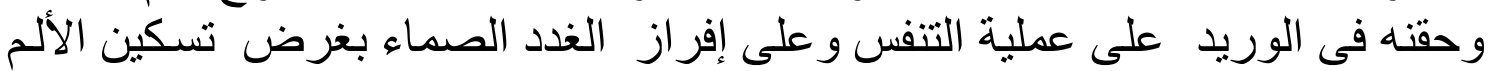

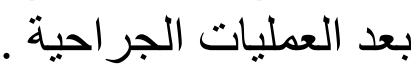

الختير 40 مريضا من الجنسين من الفئة الاولى و الثانية (تبعا لتقسيم الجمعية

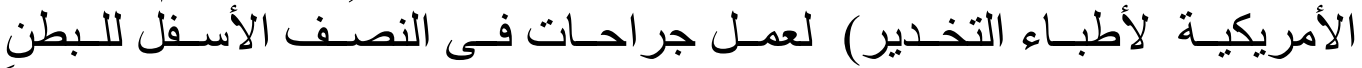

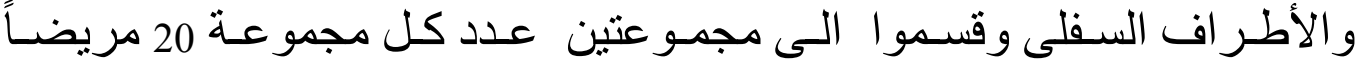

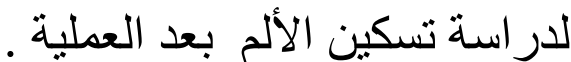

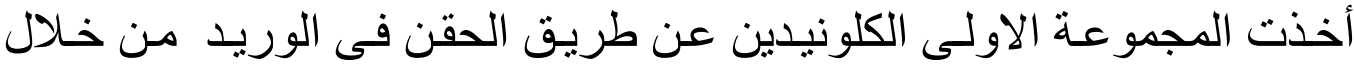

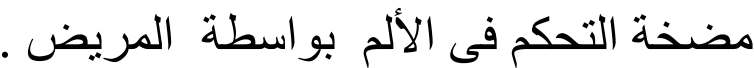

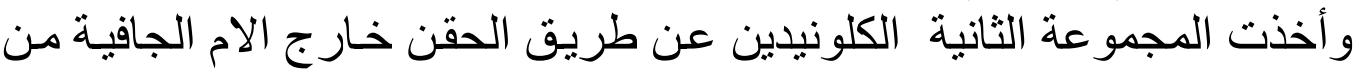

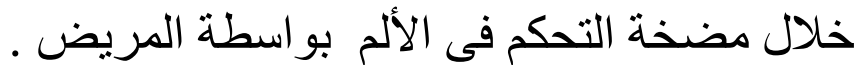

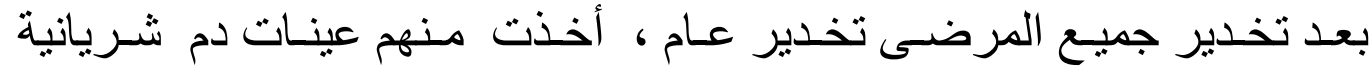
ووريدية فى مو اعيد متتالية وثابتة لقياس نسبة الغاز ات بالادم ونسبة الاندورفين

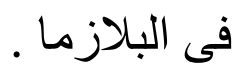

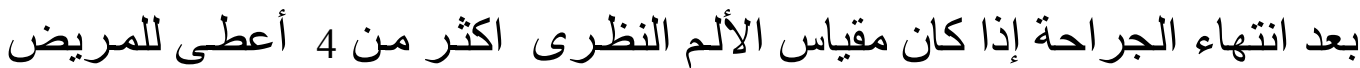

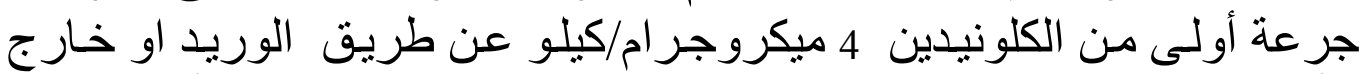

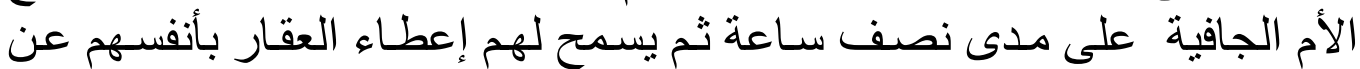

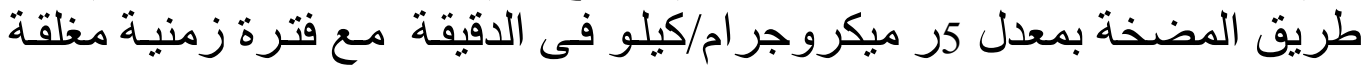

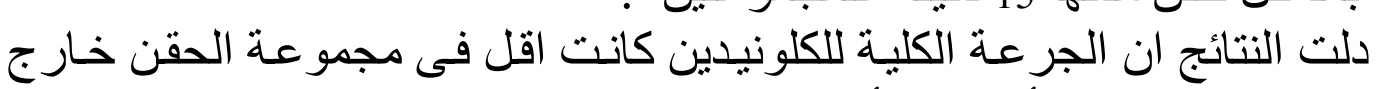

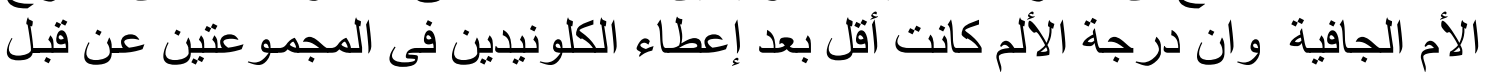

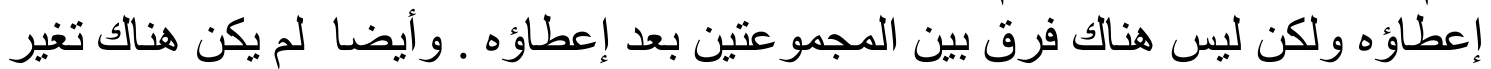

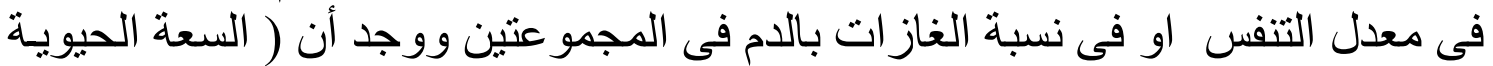




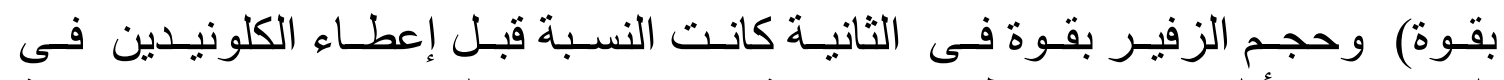

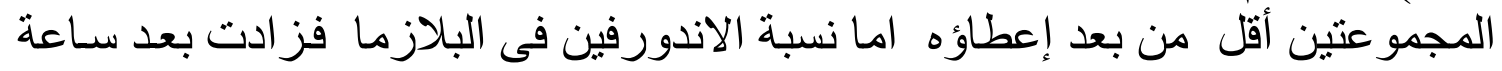

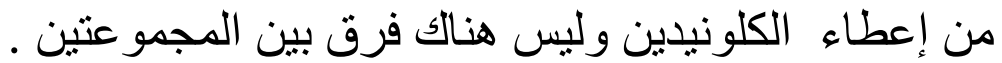

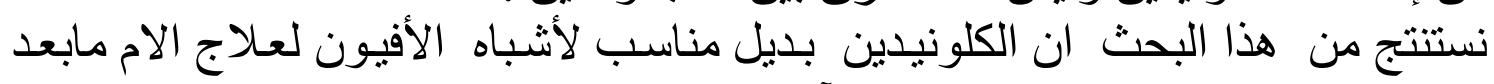

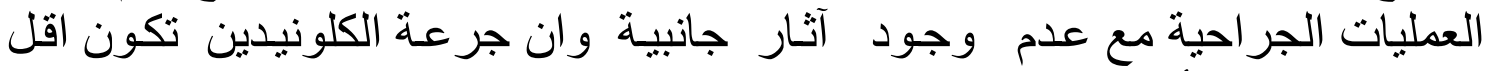

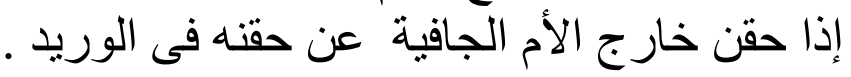

